\title{
Activating EGFR Gene Mutation Negative
}

National Cancer Institute

\section{Source}

National Cancer Institute. Activating EGFR Gene Mutation Negative. NCI Thesaurus.

Code C134494.

A genetic finding indicating that mutations in the EGFR gene which encode constitutively active forms of the epidermal growth factor receptor protein are not present in a sample. 